\title{
Calcium Levels and Limestone Particle Size in the Diet of Commercial Layers at the End of the First Production Cycle*
}

\begin{tabular}{l} 
Author(s) \\
\hline Pelicia $K^{1}$ \\
Garcia $E^{2 A}$ \\
Móri $C^{3}$ \\
Faitarone ABG ${ }^{3}$ \\
Silva AP3 \\
Molino $\mathrm{AB}^{3}$ \\
Vercese $\mathrm{F}^{3}$ \\
Berto DA \\
1 Professor Ph.D. and Researcher of the \\
Department of Animal Science of the School \\
of Agronomy and Animal Sciences, \\
Universidade José do Rosário Vellano - \\
UNIFENAS, Alfenas campus, MG, Brazil. \\
2 Associate Professor of the Department of \\
Animal Production, FMVZ/UNESP, Campus \\
Botucatu, SP, Brazil. \\
3 Graduate students of the Post-Graduation \\
Program in Animal Science, FMVZ/UNESP, \\
Campus Botucatu, SP, Brazil. \\
* Part of the Ph.D. thesis of the first author of \\
the Post-Graduation Program of the School \\
of Veterinary Medicine and Animal Sciences, \\
UNESP, Botucatu campus, SP. Brazil
\end{tabular}

\section{Mail Address}

Kleber Pelícia

Rua Dr. João Candido Villas Boas, 351

Vila Pinheiro

18.609-690. Botucatu, SP, Brasil.

Tel: (14) 38825735 / 3811-7185 / 3811-7189

E-mail: fokleber@hotmail.com

\section{Keywords}

Egg production, limestone, marketable eggs, nutrition, poultry.

\section{Acknowledgements}

The authors thank Coordenação de Aperfeiçoamento de Pessoal de Nível Superior (CAPES) for funding this study and UNESP/ UNIFENAS.

Arrived: August/2008

Approved: May/2009

\section{ABSTRACT}

This study evaluated the effect of dietary calcium levels and limestone particle size distribution on first-cycle layer performance and egg quality. A completely randomized experimental design in $4 \times 3$ factorial arrangement (four Ca levels - 3.0, 3.5, 4.0, 4.5\%; and three limestone particle size distributions - $100 \%$ fine, $50 \%$ fine and $50 \%$ coarse, $30 \%$ fine and $70 \%$ coarse) was applied, totaling 12 treatments with six replicates of eight birds each. The treatments did not influence the most of evaluated performance and internal and external egg quality parameters. However, limestone particle size distribution quadratically affected with percentage of defective eggs, with the lowest percentage obtained with the distribution $61.75 \%$ fine limestone and $38.25 \%$ coarse limestone. Increasing dietary $\mathrm{Ca}$ levels significantly increased eggshell weight per surface area and the percentage of Ca excreted in the feces. It was concluded that the combination of the highest dietary $\mathrm{Ca}$ level $(4.5 \%)$ with $50 \%$ replacement of fine-particle limestone by coarse limestone results in better eggshell and increases the number of marketable eggs.

\section{INTRODUCTION}

Calcium is one of the essential minerals in poultry nutrition. In addition to its vital functions as the main component of bone structure and participation in acid-base balance and enzymatic system, calcium is the also the main component of the eggshell. It is estimated that each egg contains $2.2 \mathrm{~g}$ of calcium, present mainly in the eggshell. Calcium supplementation is required in animal feeds, as most consist of grains and its byproducts, which have very low calcium (Peixoto \& Rutz, 1988).

Diets containing calcium below the nutritional requirements of layers impair performance and egg quality (Keshavarz, 1986). On the other hand, excessive dietary calcium can reduce feed intake, cause soft feces, and increase chalky deposits in the eggshell (Vicenzi, 1996). Birds absorb a higher percentage of calcium when it is supplemented in larger particles, suggesting that the longer retention time of larger limestone particles in the gizzard (Rao \& Roland, 1989) make calcium more available during the period of eggshell formation. When limestone particle size is reduced, its solubility increases (Oliveira, 1995). Scott \& Mullenhoff (1970) observed that the supply of large particles of calcium sources, such as oyster shell, increased their retention in the gizzard. This allowed continuous calcium supply to the bird also during the night, when egg is formed, maintaining high blood calcium levels as it happens when highcalcium diets are fed.

Calcium supplementation influences eggshell quality. Calcium has several functions in bird metabolism and it is the main component of the eggshell. Dietary calcium levels, particle size and solubility, according 
Pelicia K, Garcia E, Móri C, Faitarone ABG, Silva AP, Molino $A B$, Vercese F, Berto DA
Calcium Levels and Limestone Particle Size in the Diet of Commercial Layers at the End of the First Production Cycle to source, influence eggshell quality. Therefore, the knowledge on the quality of feedstuffs used for bird feeding is essential to promote better performance.

The present study aimed at determining the effects of calcium levels and limestone particle size on the performance, egg quality, and calcium excretion in commercial layers at the end of the first production cycle.

\section{MATERIAL AND METHODS}

The experiment was carried out at the experimental facilities of the Poultry Sector of the School of Veterinary Medicine and Animal Science, UnespUniversidade Estadual Paulista, Botucatu, SP, Brazil.

In this study, 576 58-week-old Hisex Brown ${ }^{\circledR}$ layers in their first production cycle were used.

Birds were housed in a layer house equipped with 92 metal cages $(1.00 \mathrm{~m}$ long $\times 45 \mathrm{~cm}$ deep $\times 40 \mathrm{~cm}$ high). A photoperiod of 17 hours of light per day was applied.

A completely randomized experimental design with a 3x4 factorial arrangement, consisting of four calcium levels $(3.0,3.5,4.0$, and $4.5 \%)$ and three limestone particle size (mean geometric diameter - MGD) distributions ( $100 \%$ fine $(0.18 \mathrm{~mm}), 50 \%$ fine $(0.18 \mathrm{~mm})$ and $50 \%$ coarse $(3.13 \mathrm{~mm}), 30 \%$ fine $(0.18 \mathrm{~mm})$ and $70 \%$ coarse $(3.13 \mathrm{~mm})$, with six replicates per treatment and eight birds per experimental units, totaling 576 birds and 72 cages (experimental unit).

Birds were distributed according to the following treatments: $3.0 \%$ calcium with $100 \%$ fineparticle limestone (T1), 3.0\% calcium with 50\% fineparticle limestone and $50 \%$ coarse-particle limestone (T2), 3.0\% calcium with 30\% fine-particle limestone and $70 \%$ coarse-particle limestone (T3), 3.5\% calcium with $100 \%$ fine-particle limestone (T4), 3.5\% calcium with $50 \%$ fine-particle limestone and $50 \%$ coarseparticle limestone (T5), 3.5\% calcium with 30\% fineparticle limestone and $70 \%$ coarse-particle limestone (T6), $4.0 \%$ calcium $100 \%$ fine-particle limestone (T7), $4.0 \%$ calcium with $50 \%$ fine-particle limestone and $50 \%$ coarse-particle limestone (T8), 4.0\% calcium with $30 \%$ fine-particle limestone and $70 \%$ coarse-particle limestone (T9), 4.5\% calcium $100 \%$ fine-particle limestone (T10), 4.5\% calcium with 50\% fine-particle limestone and 50\% coarse-particle limestone (T11), $4.5 \%$ calcium with $30 \%$ fine-particle limestone and $70 \%$ coarse-particle limestone (T12).

A limestone particle size was analyzed according to the method described by Zanotto \& Bellaver (1996).

In-vitro solubility was evaluated according to the method described by Cheng \& Coon (1990a) from the University of Minnesota (weight-loss percentage method).

Limestone was analyzed as to calcium and magnesium content by EDTA chelatometric method (Brasil, 1988).

Birds were offered feed and water ad libitum during the entire experimental period (58 to 70 weeks). Feeds contained equal energy level $(2.790 \mathrm{kcal} \mathrm{ME} / \mathrm{kg}$ feed), and were based on corn, soybean meal, and wheat, supplying the birds' nutritional requirements, and adjusted according to Rostagno (2000), except for calcium, as shown in Table 1.

\begin{tabular}{lrrrr}
\hline Table 1 - Percentage and calculated compositions of the \\
experimental diets. \\
\cline { 2 - 5 } Ingredients (\%) & \multicolumn{4}{c}{ Treatments } \\
\cline { 2 - 5 } & T1-3 & T4-6 & \multicolumn{1}{c}{ T7-9 } & T10-12 \\
\hline Corn & 65.801 & 65.412 & 64.984 & 64.579 \\
Soybean meal 45\% & 19.638 & 20.246 & 20.843 & 21.446 \\
Wheat bran & 5.135 & 3.658 & 2.23 & 0.772 \\
Calcitic limestone & 6.49 & 7.728 & 8.965 & 10.207 \\
Dicalcium phosphate & 1.27 & 1.288 & 1.309 & 1.325 \\
Soybean oil & 1.00 & 1.00 & 1.00 & 1.00 \\
DL-Methionine & 0.116 & 0.118 & 0.119 & 0.121 \\
Salt (NaCl) & 0.35 & 0.35 & 0.350 & 0.35 \\
Vitamin supplement* & 0.10 & 0.10 & 0.10 & 0.10 \\
Mineral supplement** & 0.10 & 0.10 & 0.10 & 0.10 \\
Total & 100.00 & 100.00 & 100.00 & 100.00 \\
\hline Calculated nutritional levels & \multicolumn{4}{c}{} \\
\hline Calcium (\%) & 3.00 & 3.500 & 4.000 & 4.500 \\
Available phosphorus (\%) & 0.340 & 0.340 & 0.340 & 0.340 \\
Metabolizable energy (kcal/ kg) & 2790 & 2790 & 2790 & 2790 \\
Crude protein (\%) & 15.500 & 15.500 & 15.50 & 15.500 \\
Total lysine (\%) & 0.740 & 0.740 & 0.740 & 0.740 \\
Total methionine+cystine (\%) & 0.640 & 0.640 & 0.640 & 0.640 \\
Total methionine (\%) & 0.350 & 0.350 & 0.350 & 0.350 \\
Sodium (\%) & 0.150 & 0.150 & 0.150 & 0.150 \\
\hline
\end{tabular}

*Vitamin supplement per kg feed: Vit. A - 7000 IU, Vit. D3 - 2000 IU, Vit. and - 5 mg, Riboflavin - 3 mg, Vit. K3 - 1.6 mg - Vit. B12 - $8 \mu \mathrm{g}$, Niacin - $20 \mathrm{mg}$, Pantothenic acid - $5 \mathrm{mg}$, Antioxidant - $15 \mathrm{mg}$. ** Mineral supplement per $\mathrm{kg}$ feed: $\mathrm{Fe}-50 \mathrm{mg}, \mathrm{Cu}-8 \mathrm{mg}, \mathrm{Mn}-70$ $\mathrm{mg}, \mathrm{Zn}-50 \mathrm{mg}, \mathrm{l}-1.2 \mathrm{mg}$, Se $-0.2 \mathrm{mg}$.

The following performance parameters were evaluated: mortality, egg production, total number of defective or broken eggs, individual feed intake, average egg weight, egg mass, feed conversion ratio per dozen eggs, and feed conversion ratio per $\mathrm{kg}$ of eggs produced. Egg production data were collected daily, and egg weight and feed intake were determined weekly.

Eggshell quality and internal egg quality were evaluated every 28 days during a total period of 84 days. The obtained results were recorded and presented as mean values for the 84-day period.

The following egg quality parameters were 
Pelicia K, Garcia E, Móri C, Faitarone ABG, Silva AP, Molino $A B$, Vercese $F$, Berto DA
Calcium Levels and Limestone Particle Size in the Diet of Commercial Layers at the End of the First Production Cycle determined: specific gravity, eggshell percentage, eggshell weight per surface area, yolk color, yolk percentage, albumen percentage, albumen height, yolk height, egg weight, and Haugh units. Eggshell weight per surface area (EWSA) was expressed in mg/ $\mathrm{cm}^{2}$, according to Abdallah et al. (1993), and obtained using the formula: EWSA $=\left\{\mathrm{EsW} /\left[3.9782 \times\left(\mathrm{EW}^{0.7056}\right)\right]\right\}$ x 1000, where: EsW = eggshell weight, $E W=$ egg weight. Haugh units were determined applying the formula: $\mathrm{HU}=100 \log \left(\mathrm{H}+7.57-1.7 \mathrm{~W}^{0.37}\right)$, where: $\mathrm{H}$ = albumen height $(\mathrm{mm})$ and $\mathrm{W}=$ egg weight $(\mathrm{g})$.

Blood Ca level was determined according to the method of the Perkin-Elmer Corporation (1996).

Excreta Ca percentage was analyzed according to the method of Brasil (1988).

The following statistical model was applied:

$$
\text { Yijk }=\mu+C a i+L P S j+C a P S i j k+e i j k l
$$

\section{Where}

Yijk = observation of the kth experimental unit at Cai calcium level and LPSj limestone particle size distribution, $\mu=$ general mean, $C$ ai $=$ effect of ith calcium level $(3.0,3.5,4.0$, or $4.5 \%)$, LPSj $=$ effect of jth limestone particle size distribution (100\% fine, 50\% fine $+50 \%$ coarse, or $30 \%$ fine $+70 \%$ coarse), CaLPSijk = effect of the interaction Ca $\times$ LPS, eijkl = random error associated to each observation.

The results were submitted to analysis of variance, and means with statistical difference were compared using SAS (2000) statistical package. Calcium level and limestone particle size estimates were established by linear, quadratic, or cubic analysis of regression, considering the averages obtained for the entire experimental period.

\section{RESULTS AND DISCUSSION}

Table 2 shows the results of the analyses of limestone particle size determination, in vitro solubility, and limestone calcium and magnesium composition. Limestone particle size was uniform within each particle size class.

\begin{tabular}{|c|c|c|c|c|}
\hline Limestone & $\begin{array}{l}\text { MGD } \\
(\mathrm{mm})\end{array}$ & $\begin{array}{c}\text { in vitro } \\
\text { solubility (\%) }\end{array}$ & $\begin{array}{l}\mathrm{Ca} \\
(\%)\end{array}$ & $\begin{array}{l}\mathrm{Mg} \\
(\%)\end{array}$ \\
\hline Coarse & 3.13 & 13.35 & 36.4 & 0.96 \\
\hline Fine & 0.18 & 19.54 & 35.7 & 0.84 \\
\hline
\end{tabular}

$\mathrm{MGD}=$ mean geometric diameter .
The in vitro solubility results show that particle size is related to solubility: in vitro solubility decreased as particle size increased, which is consistent with the findings of Cheng \& Coon (1990a). These authors mention that solubility is better to evaluated limestone quality than particle size, suggesting optimum solubility values of 12 to $14 \%$. The analyzed composition of limestone indicated values somewhat lower than those observed by Butolo (2002) for calcium and magnesium, of $37 \%$ and $1 \%$, respectively.

Average, maximum, and minimum temperatures recorded during the experimental period were 23, 30, and $19{ }^{\circ} \mathrm{C}$, respectively, and the recorded average, maximum, and minimum relative humidity were 72,87 , and $44 \%$, respectively. The recorded temperatures and air relative humidity are within the recommended ranges of 23 to $24{ }^{\circ} \mathrm{C}$ and 65 to $75 \%$, respectively.

\section{Performance}

There was no significant interaction $(p>0.05)$ between $\mathrm{Ca}$ levels and limestone particle size distribution, nor any significant effect of these factors on bird livability, which was $99 \%$ in average. However, it must be noted that inadequate intake of $\mathrm{Ca}$ may cause skeletal abnormalities, resulting in leg problems and consequently low feed intake, as the birds remain lying, which may eventually cause mortality (Maynard et al., 1984).

Table 3 shows the performance results. Again, no significant interaction ( $p>0.05$ ) was detected between Ca levels and limestone particle size distribution for the analyzed parameters, nor any effect of these factors on laying percentage, egg weight, egg mass, feed intake, FCR/dozen eggs, or FCR/kg eggs. However, $\mathrm{Ca}$ intake linearly increased as $\mathrm{Ca}$ level increased in the diet.

Keshavarz (1986) obtained lower egg production in layers fed 2 and $5 \%$ calcium as compared to the control birds receiving 3.5\% calcium. The difference in egg production observed in the present study as compared to that obtained Keshavarz (1986) may be due to the fact that $5 \%$ Ca level was excessive, which was detrimental to the birds (Roland, 1986), resulting in lower egg production.

The absence of effects on performance parameters observed in the present study may be explained by the lack of differences in blood Ca levels (Table 7) despite the increase in Ca intake (Table 3). Although feed intake was not statistically different among treatments, there was a trend of feed intake to decrease as dietary Ca levels increased (Table 3); if 
Pelicia K, Garcia E, Móri C, Faitarone $A B G$, Silva AP, Molino $A B$, Vercese $F$, Berto $D A$
Calcium Levels and Limestone Particle Size in the Diet of Commercial Layers at the End of the First Production Cycle

\begin{tabular}{|c|c|c|c|c|c|c|c|}
\hline $\begin{array}{l}\text { Ca level } \\
(\%)\end{array}$ & $\begin{array}{l}\text { Lay } \\
(\%)\end{array}$ & $\begin{array}{c}\text { Egg weight } \\
(\mathrm{g})\end{array}$ & $\begin{array}{c}\text { Egg mass } \\
\text { (g) }\end{array}$ & $\begin{array}{l}\text { Feed intake } \\
\text { (g/bird/day) }\end{array}$ & $\begin{array}{c}\text { Ca intake } \\
\text { (g/bird/day) }\end{array}$ & $\begin{array}{l}\text { FCR/ } \\
\mathrm{dz}\end{array}$ & $\begin{array}{c}\text { FCR/ } \\
\mathrm{kg}\end{array}$ \\
\hline 3.0 & 84.36 & 66.95 & 56.49 & 120.9 & $3.63^{a}$ & 1.761 & 2.194 \\
\hline 3.5 & 86.74 & 67.49 & 58.54 & 116.5 & $4.08 \mathrm{~b}$ & 1.679 & 2.075 \\
\hline 4.0 & 88.69 & 66.82 & 59.24 & 119.2 & $4.78 c$ & 1.685 & 2.102 \\
\hline 4.5 & 86.42 & 67.43 & 58.19 & 117.1 & $5.27 d$ & 1.683 & 2.082 \\
\hline \multicolumn{8}{|l|}{ Particle size } \\
\hline Fine & 84.32 & 67.34 & 58.70 & 117.00 & 4.39 & 1.671 & 2.071 \\
\hline $50 \%$ coarse & 83.58 & 67.13 & 57.89 & 117.66 & 4.41 & 1.695 & 2.104 \\
\hline $70 \%$ coarse & 83.07 & 67.05 & 57.77 & 120.70 & 4.51 & 1.740 & 2.164 \\
\hline \multicolumn{8}{|l|}{ Probability } \\
\hline Ca level & NS & NS & NS & NS & $p<0.001 *$ & NS & NS \\
\hline Particle size & NS & NS & NS & NS & NS & NS & NS \\
\hline Ca level* particle size & NS & NS & NS & NS & NS & NS & NS \\
\hline CV (\%) & 6.70 & 3.88 & 6.56 & 5.75 & 5.51 & 6.78 & 6.96 \\
\hline
\end{tabular}

NS $=(p>0.05) . *$ Significant linear effect $(p<0.05)$.

feed intake had remained constant, Ca intake would have increased even more, possibly increasing blood Ca levels.

Faria (2002) working with limestone particle size distributions of 0.15 to $0.60 \mathrm{~mm}, 0.60$ to $1.20 \mathrm{~mm}$, or 1.18 to $2.0 \mathrm{~mm}$, did not observe any effect of limestone particle size on egg production either. However, Cheng \& Coon (1990b) concluded that the egg production of layers fed pulverized limestone was significantly lower. Batista \& Cruz (2005) observed that a diet with 100\% fine-particle limestone and $4.2 \%$ calcium increased egg production.

The study carried out by Faria (2002) also did not detect any significant effect of dietary calcium levels or of limestone particle size on egg weight. On the other hand, Guinotte \& Nys (1991) reported that layers fed coarser particles of limestone produced heavier eggs as compared to those consuming pulverized limestone.

In the study of Ito et al. (2006), feed intake was also not affected by limestone particles of $0.5 \mathrm{~mm}$ and $3.0 \mathrm{~mm}$. The authors replaced fine limestone $(0.5 \mathrm{~mm})$ by coarse limestone $(3.0 \mathrm{~mm})$ in up to $30 \%$, according to the recommendations of Roland \& Bryant (1999), who considered that the replacement of fine- by coarseparticle limestone should not exceed $50 \%$ in order not to compromise feed intake. Nevertheless, in the present study, where fine limestone was replaced by coarse limestone in up to $70 \%$, there was no significant reduction in feed intake. Conversely, Faria (2002) observed that limestone particle sizes between 0.6 and $1.2 \mathrm{~mm}$ increased feed intake, and Geraldo et al. (2006 a) found higher feed intake in layers fed fine-particle limestone $(0.135 \mathrm{~mm})$ as compared to coarse-particle limestone $(0.899 \mathrm{~mm})$.

The results of the present study are consistent with the findings of Ito et al. (2006), who also did not observe any difference in feed conversion ratio per dozen eggs or per kg eggs feeding layers with different limestone particle sizes. On the other hand, Faria (2002) found better feed conversion ratio results for particle sizes between 0.15 and $0.6 \mathrm{~mm}$.

Rodrigues et al. (2005) also did not detect any effect of dietary $\mathrm{Ca}$ levels on feed conversion ratio per dozen eggs ( $F R C / \mathrm{dz}$ ) or per kg eggs (FCR/kg).

The contradictory results produced by Ca levels and limestone particle size distribution in the studies mentioned above may be due to the fact that chickens respond differently to determined $\mathrm{Ca}$ levels and limestone particle size distribution combinations, as well as if we consider that each Ca source, despite presenting equal particle size, may have different solubility.

Table 4 does not show significant interaction ( $p>0.05$ ) between $\mathrm{Ca}$ levels and limestone particle size distribution for the analyzed parameters, nor any effect of these factors on the percentages of broken eggs and intact eggs. However, limestone particle size distribution significantly $(p<0.05)$ influenced the percentage of defective eggs.

\begin{tabular}{|c|c|c|c|}
\hline $\begin{array}{c}\text { Ca level (\%) } \\
\text { eggs }(\%)\end{array}$ & $\begin{array}{l}\text { Broken } \\
\text { eggs (\%) }\end{array}$ & $\begin{array}{l}\text { Defective } \\
\text { eggs (\%) }\end{array}$ & Intact \\
\hline 3.0 & 1.99 & 0.37 & 82.00 \\
\hline 3.5 & 2.46 & 0.59 & 83.69 \\
\hline 4.0 & 2.83 & 0.60 & 85.26 \\
\hline 4.5 & 2.33 & 0.47 & 83.62 \\
\hline \multicolumn{4}{|l|}{ Particle size } \\
\hline Fine & 2.43 & 0.41 & 81.48 \\
\hline $50 \%$ coarse & 2.17 & 0.40 & 81.01 \\
\hline $70 \%$ coarse & 2.60 & 0.71 & 79.76 \\
\hline \multicolumn{4}{|l|}{ Probability } \\
\hline Ca level & NS & NS & NS \\
\hline Particle size & NS & $\mathrm{P}<0.05^{*}$ & NS \\
\hline Ca level*particle size & NS & NS & NS \\
\hline CV $(\%)$ & 41.40 & 95.94 & 7.07 \\
\hline
\end{tabular}

*Significant quadratic effect. 
Pelicia K, Garcia E, Móri C, Faitarone ABG, Silva AP, Molino $A B$, Vercese $F$, Berto DA
Calcium Levels and Limestone Particle Size in the Diet of Commercial Layers at the End of the First Production Cycle
Egg loss (defective and broken eggs) results are consistent with those obtained by Oliveira et al. (2002), who worked with 2.8 to $4.4 \%$ Ca levels. On the other hand, Teixeira (1982) observed that egg losses were reduced as dietary Ca levels increased. Chowdhury \& Smith (2002) also did not observe eggshell deficiencies working with dietary Ca levels of $2.5,3.0,3.5$, or $4.0 \%$.

There was a significant quadratic effect $(p<0.05)$ of limestone particle size distribution on the percentage of defective eggs (Figure 1), with the highest percentage $(0.71 \%)$ when $30 \%$ fine limestone and $70 \%$ coarse limestone were fed, and the lowest percentage $(0.37 \%)$ with $61.75 \%$ fine and $38.25 \%$ coarse limestone.

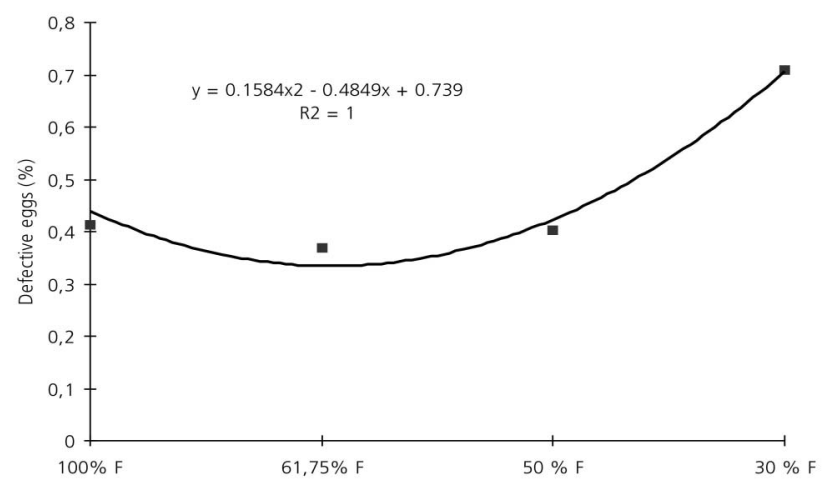

Limestone particle size distribution

Figure 1 - Effect of limestone particle size distribution on the percentage of defective eggs.

Geraldo et al. (2006b) did not detect any influence of limestone particle size $(0.135 \mathrm{~mm}$ or $0.899 \mathrm{~mm})$ on egg loss, which may be explained by the small variation in particle size used in this study.

The results obtained in the analysis of regression for defective eggs may be explained by Rao \& Roland (1992), who observed that the time required to release the calcium derived from dietary limestone is influenced by limestine particle size. When particle size distribution contained more than $50 \%$ coarse limestone, calcium release decreased due to the lower solubility of $\mathrm{Ca}$ in coarser particles, explaining the higher percentage of broken and defective eggs caused by limestone particle size distribution of $30 \%$ fine and $70 \%$ coarse particles.

\section{External egg quality}

Table 5 shows external egg quality results, with no significant interaction ( $p>0.05$ ) between $C a$ levels and limestone particle size distribution on the analyzed parameters, nor any effects of these factors on egg specific gravity, eggshell thickness, or eggshell percentage. However, Ca levels influenced $(p<0.05)$ eggshell per surface area (EWSA).

Geraldo et al. (2006 b) also did not observe any effect of limestone particle size distribution on egg specific gravity. However, Cheng \& Coon (1990b) and Ito et al. (2006) showed that coarser limestone particle size improved (increased) egg specific gravity as compared to finer particles.

Clunies et al. (1992) increased dietary Ca level from de 3.5 to $4.5 \%$, and observed an increase in eggshell percentage. Chowdhury \& Smith (2002) found an increasing linear effect of Ca level on eggshell weight.

The difference between results obtained by Clunies et al. (1992), who worked with similar dietary Ca levels as the present study, and those verified here may be due to higher feed intake of the birds of Clunies' study, and therefore higher $\mathrm{Ca}$ intake, as compared to our birds.

Faria (2002) observed that dietary Ca levels need to be increased as limestone particle size is reduced in order to maintain eggshell percentage. At the lowest dietary Ca level (3.2\%), the author observed an average increase of $8.48 \%$ in eggshell weight when feeding coarser limestone (1.18 to $2.0 \mathrm{~mm}$ ).

\begin{tabular}{|c|c|c|c|c|}
\hline Ca level (\%) & Specific gravity $\left(\mathrm{g} / \mathrm{cm}^{3}\right)$ & Thickness (mm) & Eggshell (\%) & EWSA $\left(\mathrm{mg} / \mathrm{cm}^{2}\right)$ \\
\hline 3.0 & 1.089 & 0.413 & 9.67 & 83.82 \\
\hline 3.5 & 1.091 & 0.416 & 9.88 & 84.62 \\
\hline 4.0 & 1.090 & 0.413 & 9.92 & 85.72 \\
\hline 4.5 & 1.091 & 0.413 & 9.79 & 87.00 \\
\hline \multicolumn{5}{|l|}{ Particle size } \\
\hline Fine & 1.091 & 0.418 & 9.91 & 86.03 \\
\hline $50 \%$ coarse & 1.090 & 0.410 & 9.67 & 85.79 \\
\hline $70 \%$ coarse & 1.089 & 0.413 & 9.86 & 84.05 \\
\hline \multicolumn{5}{|l|}{ Probability } \\
\hline Ca level & NS & NS & NS & $p<0.05^{*}$ \\
\hline Particle size & NS & NS & NS & NS \\
\hline Ca level*particle size & NS & NS & NS & NS \\
\hline CV $(\%)$ & 0.28 & 3.61 & 4.24 & 3.69 \\
\hline
\end{tabular}

*Significant linear effect 
Pelicia K, Garcia E, Móri C, Faitarone ABG, Silva AP, Molino $A B$, Vercese $F$, Berto DA
Calcium Levels and Limestone Particle Size in the Diet of Commercial Layers at the End of the First Production Cycle
EWSA was significantly influenced $(p<0.05)$ by dietary $\mathrm{Ca}$ levels, presenting linear increase $(p<0.05)$ as Ca levels increased, as shown in Figure 2. However, Oliveira et al. (2002) did not observe any effect of $\mathrm{Ca}$ levels on EWSA, probably because the feed intake and the Ca intake of the birds in the trial were below those determined for the birds in the present study.

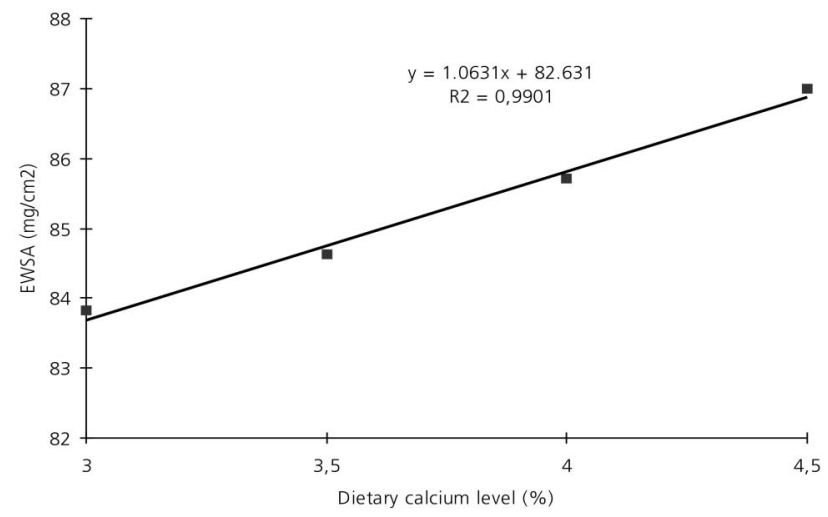

Figure 2 - Effect of dietary calcium levels on eggshell weight per surface area.

Gordon \& Roland (1997) reported that increasing dietary $\mathrm{Ca}$ levels reduced in vivo limestone solubility, thereby determining a slower $\mathrm{Ca}$ release and better Ca utilization for eggshell formation, consequently increasing eggshell weight per surface area. This may have also occurred in the present experiment.

\section{Internal egg quality}

Table 6 presents internal egg quality results. There was no significant interaction $(p>0.05)$ between $\mathrm{Ca}$ levels and limestone particle size distribution on the analyzed parameters, nor any effects of these factors on the studied parameters.

\begin{tabular}{lcccc}
\hline \multicolumn{4}{l}{ Table $\mathbf{6}$ - Internal egg quality layers fed different Ca levels and } \\
limestone particle size distribution. \\
\hline $\begin{array}{c}\text { Yolk } \\
\mathbf{( \% )}\end{array}$ & $\begin{array}{c}\text { Yolk } \\
\text { color* }\end{array}$ & $\begin{array}{c}\text { Albumen } \\
\mathbf{( \% )}\end{array}$ & $\begin{array}{c}\text { Haugh } \\
\text { unit }\end{array}$ \\
\hline 3.0 & 24.80 & 8.27 & 65.00 & 84.69 \\
3.5 & 24.93 & 8.33 & 65.45 & 81.24 \\
4.0 & 25.40 & 8.14 & 64.76 & 82.50 \\
4.5 & 24.98 & 8.33 & 64.67 & 82.18 \\
Particle size & & & & \\
Fine & 24.91 & 8.20 & 64.74 & 83.68 \\
$50 \%$ coarse & 25.13 & 8.34 & 65.37 & 81.94 \\
$70 \%$ coarse & 25.03 & 8.26 & 64.80 & 82.35 \\
Probability & & & & \\
Ca level & NS & NS & NS & NS \\
Particle size & NS & NS & NS & NS \\
Ca level* particle size & NS & NS & NS & NS \\
CV (\%) & 4.00 & 3.31 & 2.48 & 5.66 \\
\hline
\end{tabular}

*Yolk color measured using Roche colorimetric fan, with color scores from 1 to $15 . N S=(p>0.05)$.
Ito et al. (2006) and Oliveira (2002) did not observe any effects of dietary Ca levels on yolk percentage, whereas Geraldo et al. (2006b), Rodrigues et al. (2005) and Oliveira (2002) also did not detect any effect of Ca levels on Haugh units. Ito et al. (2006) did not find any effect of $\mathrm{Ca}$ levels on albumen percentage and Haugh units.

As to limestone particle size distribution, Geraldo et al. (2006b) also did not find any effects on Haugh units, and lto et al. (2006) on albumen percentage and Haugh units.

Internal egg quality results obtained in the present trial are similar to many other studies because the increase in $\mathrm{Ca}$ availability both due the increase of dietary $\mathrm{Ca}$ levels and the addition of coarse limestone primarily affects eggshell quality, whereas internal egg quality is less sensitive to $\mathrm{Ca}$.

\section{Blood and excreta calcium concentrations}

Table 7 shows blood and excreta calcium contents of the evaluated birds. There was no significant interaction ( $p>0.05$ ) between Ca levels and limestone particle size distribution on the analyzed parameters, nor any effects of these factors on blood calcium levels. However, a significant effect $(p<0.05)$ of dietary $\mathrm{Ca}$ levels on excreta Ca content was detected.

\begin{tabular}{ccc}
\hline \multicolumn{3}{c}{$\begin{array}{c}\text { Table } 7 \text { - Blood and excreta calcium content of layers fed different } \\
\text { Ca levels and limestone particle size distribution. }\end{array}$} \\
\hline Ca level (\%) & $\begin{array}{c}\text { Blood Ca content } \\
\text { (mg/L) }\end{array}$ & $\begin{array}{c}\text { Excreta Ca content } \\
\text { (\%) }\end{array}$ \\
\hline 3.0 & 206.58 & 6.40 \\
3.5 & 197.42 & 9.33 \\
4.0 & 202.58 & 10.77 \\
4.5 & 192.92 & 12.27 \\
Particle size & & \\
Fine & 205.38 & 9.08 \\
$50 \%$ coarse & 213.38 & 9.61 \\
$70 \%$ coarse & 180.88 & 10.39 \\
Probability & & \\
Ca level & NS & p $<0.01 *$ \\
Particle size & NS & NS \\
Interaction & NS & NS \\
CV (\%) & 22.89 & 31.54 \\
\hline
\end{tabular}

*Significant linear effect.

The linear increase in Ca intake (Table 3) promoted by increasing dietary $\mathrm{Ca}$ levels did not result in different blood Ca levels (Table 7), which may explain the absence of effects of dietary Ca levels on internal egg quality (Table 6) and on most external egg quality (Table 5) and performance (Table 3) parameters.

A significant linear effect $(p<0.05)$ of dietary Ca levels on excreta Ca content was observed, with 
Pelicia K, Garcia E, Móri C, Faitarone ABG, Silva AP, Molino $A B$, Vercese $F$, Berto DA
Calcium Levels and Limestone Particle Size in the Diet of Commercial Layers at the End of the First Production Cycle increasing dietary $\mathrm{Ca}$ levels resulting in increasing $\mathrm{Ca}$ loss in the excreta, as shown in Figure 3.

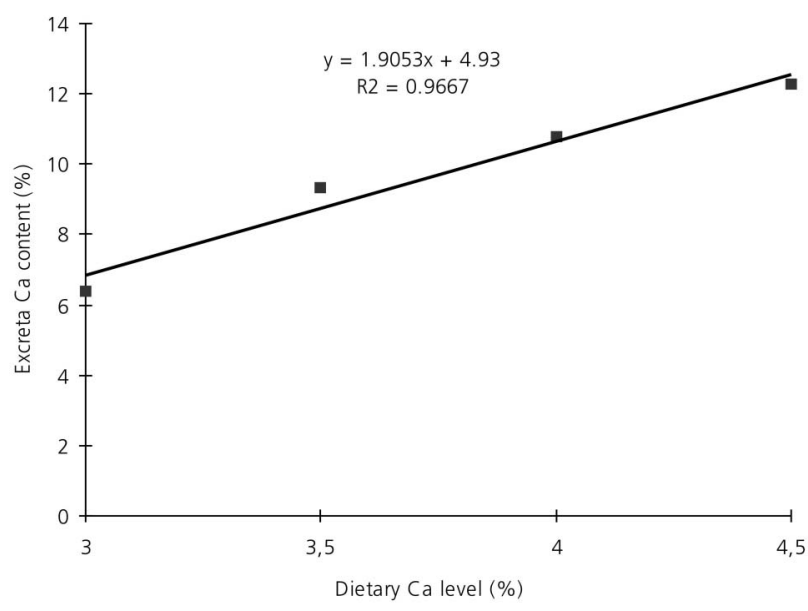

Figure 3 - Effect of dietary Ca levels on Ca loss on the excreta.

Chowdhury \& Smith (2002) also observed that increasing dietary $\mathrm{Ca}$ levels linearly increased $\mathrm{Ca}$ loss in the excreta and reduced $\mathrm{Ca}$ retention. The excreta $\mathrm{Ca}$ contents determined in the present study may be explained by Keshavarz \& Nakajima (1993), who asserted that the increase in dietary Ca levels makes Ca pass through the digestive system without being absorbed.

In the present study, it was expected that coarser limestone increased $\mathrm{Ca}$ retention in the intestines, improving eggshell quality, as mentioned by Guinote \& Nys (1991), particularly because it was less soluble, as shown in Table 2.

The contradictory responses as compared to other studies using limestone with the same particle size and same Ca levels may be due to the variation in the solubility of each Ca source, thereby increasing or reducing $\mathrm{C}$ a retention in the body.

The study on the interaction of different dietary $\mathrm{Ca}$ levels with different limestone particle sizes and calcium sources still warrants further research due to the divergent results obtained in different experiments, taking also into account that excessive calcium prevents the absorption of some trace minerals and that each calcium source has its own physical and chemical peculiarities.

\section{CONCLUSIONS}

In the present study, when dietary Ca levels were increased, eggshell quality increased, as demonstrated by the increase in eggshell weight per surface area. However, there were no effects on layer performance.
When limestone particle size is considered, the substitution of fine limestone by $70 \%$ coarse limestone may increase the rate of defective eggs.

\section{REFERENCES}

Abdallah AG, Harms RH, El-Husseiny O. Various methods of measuring shell quality in relation to percentage of cracked eggs. Poultry Science 1993; 72(11):2038-2043.

Batista AC, Cruz FGG. Fontes e níveis de cálcio sobre o desempenho e qualidade da casca em poedeiras comerciais em clima quente e úmido [CD-ROM]. Anais da 42a Reunião Anual da Sociedade Brasileira de Zootecnia; 2005; Goiânia, Goiás. Brasil: Sociedade Brasileira de Zootecnia; 2005.

Brasil. Ministério da Agricultura, Secretaria Nacional de Defesa Agropecuária. Laboratório Nacional de Referência Vegetal. Análises de corretivos, fertilizantes e inoculantes métodos oficiais. Brasília (DF); 1988. 104 p.

Butolo JE. Qualidade de ingredientes na alimentação animal. Campinas: Brasileiro de Nutrição Animal; 2002.

Cheng TK, Coon CN. Comparison of various in vitro methods for the determination of limestone solubility. Poultry Science 1990a; 69(12):2204-2208.

Cheng TK, Coon CN. Effect on layer performance and shell quality of switching limestones with different solubilites. Poultry Science 1990b; 69(12):2199-2203.

Chowdhury SR, Smith TK. Dietary interaction of 1.4-diaminobutane (putrescine) and calcium on eggshell quality and performance in laying hens. Poultry Science 2002; 81:84-91.

Clunies M, Parks D, Leeson S. Calcium and phosphorus metabolism and eggshell thickness in laying hens producing tick or thin shells. Poultry Science 1992; 71(3):490-498.

Faria LV. Granulometria do calcário calcítico and níveis de cálcio para poedeiras comerciais em segundo ciclo de produção [dissertação]. Lavras (MG):Universidade Federal de Lavras; 2002. 61 p.

Geraldo A. et al. Níveis de cálcio e granulometrias do calcário para frangas de reposição no período de 3 a 12 semanas de idade. Revista Brasileira de Zootecnia 2006a; 35(1):113-118.

Geraldo A. et al. Níveis de cálcio e granulometrias do calcário para frangas e seus efeitos sobre a produção e qualidade de ovos. Revista Brasileira de Zootecnia 2006; 35(4 Suppl):1720-1727.

Gordon RW, Roland DA. The influence of environmental temperature on in vivo limestone solubilization, feed passage rate, and gastrointestinal pH in laying hens. Poultry Science 1997; 76: 683-688.

Guinotte F, Nys Y. Effects of particle size and origin of calcium sources on eggshell quality and bone mineralization in egg laying hens. Poultry Science 1991; 70:583-592. 


\section{Pelicia K, Garcia E, Móri C, Faitarone ABG, Silva AP, Molino $A B$, Vercese $F$, Berto DA}

Calcium Levels and Limestone Particle Size in the Diet of Commercial Layers at the End of the First Production Cycle
Ito DT. et al. Efeitos do fracionamento do cálcio dietário e granulometria do calcário sobre o desempenho e qualidade dos ovos de poedeiras comerciais. Acta Scientiarum Animal Sciences 2006; 28(2):187-195.

Kehavarz K, Nakajima S. Re-evaluation of calcium and phosphorus requirements of laying hens for optimum performance and eggshell quality. Poultry Science 1993; 72(1):144-153,

Keshavarz K. The effect of variation of calcium intake on production performance and shell quality. Poultry Science 1986; 65(11):21202125.

Maynard LA. et al. Nutrição animal. 3rd ed. Rio de Janeiro: Freitas Bastos; 1984. 726 p.

Oliveira JR de. et al. Níveis de cálcio em dietas para poedeiras leves and semipesadas no segundo ciclo de produção. Ciência Agrotecnica 2002; 26(5):1060-1067.

Oliveira JEF. Níveis de cálcio, forma de fornecimento do calcário and a qualidade do ovo de poedeiras leves no segundo ciclo de postura [dissertação]. Lavras (MG): Universidade Federal de Lavras; 1995.

Peixoto RR, Rutz F. Fontes de cálcio para poedeiras comerciais. I. Calcários "Matarazzo", "Trevo Filler" and "Trevo Dolomítico". Revista Brasileira de Zootecnia 1988; (1):17-29.

Perkin-Eirmen Corporation. Anatomic absorption spectroscopy analytical methods. Norwalk; 1996. 300 p.

Rao KS, Roland DA. In vivo limestone solubilization in commercial leghorns: Role of dietary calcium level, limestone particle size, in vitro limestone solubility rate, and the calcium status of the hen. Poultry Science 1989; 69(12):2170-2176.

Rao KS, Roland DA. Improved limestone retention in the gizzard of commercial Leghorn hens. Journal Applied Poultry Research 1992; 1:6-10.

Rodrigues EA. et al. Níveis de cálcio em rações de poedeiras comerciais no segundo ciclo de postura. Acta Scientiarum Animal Sciences 2005; 27(1):49-54.

Roland DA, Bryant M. optional shell quality possible without oyster shell. Feedstuffs 1999; 71(11):18-19.

Roland DA. Egg shell quality III: calcium and phosphorus requirements of commercial Leghorns. World Poultry Science Journal 1986a; 42(2):154-165.

Rostagno HS, Albino LFT, Donzele JL, Gomes PC, Oliveira RF. et al. Tabelas brasileiras para aves e suínos: composição de alimentos e exigências nutricionais. Viçosa: Universidade Federal de Viçosa; 2000.

Statistical Analyses System [CD ROM]. User's guide. Cary; 2000.

Scott ML, Mullenhoff PA. Dietary oystershell and eggshell quality. Proceedings of the Cornell Nutrition Conference For Feed Manufactures; 1970; New York, NY; USA: Academic Press; 1970. p.24-28.
Teixeira AS. Variação granulométrica do calcário e diferentes níveis de cálcio em ração de poedeiras [dissertação]. Lavras (MG): Escola Superior de Agricultura de Lavras; 1982.

Vicenzi E. Fadiga de gaiola e qualidade da casca do ovo: aspectos nutricionais. Anais do $6^{\circ}$ Simpósio Técnico de Produção de Ovos; 1996; São Paulo, SP. Brasil: APA; 1996. p.77-91.

Zanoto DL, Bellaver C. Método de determinação da granulometria de ingredientes para uso em rações de suínos e aves. Concórdia: EMBRAPA; 1996. 5 p. [Comunicado Técnico 215]. 